\title{
Cenozoic eruptive stratigraphy and structure in Taiz area of Yemen
}

\author{
Abdul-Hamid Malek ${ }^{1}$, Mysore Ramachandraiah Janardhana ${ }^{2}$, Abdul-Aleam Ahmed Al-Qadhi ${ }^{2, *}$ \\ ${ }^{1}$ Department of Geology, Faculty of Applied Science, Taiz University, Taiz, Yemen \\ ${ }^{2}$ Department of Earth Science \& Resources Management, Yuvaraja's College, University of Mysore, Mysore-570005, India
}

\section{Email address:}

a_malek74@yahoo.com (Abdul-Hamid M.),drmrjanardhana@rediffmail.com (M. R. Janardhana), abdul.aleam@yahoo.com (Abdul-Aleam Al-Qadhi)

\section{To cite this article:}

Abdul-Hamid Malek, Mysore Ramachandraiah Janardhana, Abdul-Aleam Ahmed Al-Qadhi. Cenozoic Eruptive Stratigraphy and Structure in Taiz area of Yemen. Earth Sciences. Vol. 3, No. 3, 2014, pp. 85-96. doi: 10.11648/j.earth.20140303.13

\begin{abstract}
The present study focuses on the field description of a bimodal volcanic rock centre and fault types present in Taiz area located in the southern part of Yemen. Taiz area serves as one of the key areas to understand the Afro-Arabian bimodal volcanism and the emplacement of Afar plume and the relationship between extension tectonics and magmatism. Taiz area comprises bimodal volcanic rocks encompassing mafic and silicic lava flows and pyroclastic rocks. The lava flows were erupted in five phases - three major basic and two acid phases. Lower basalt sequence (Tb1) is the oldest and main phase of flood basalt volcanism, formed as part of a wide spread volcanism within the Afro-Arabian region. This is followed by lower silicic sequence phase (Tr1) consisting of varied assortment of lithologies such as rhyolite flows with subordinate ignimbrites, welded ash, pyroclastic breccia, and random pumice and obsidian. The middle basalt sequence phase (Tb2) has been formed from the flows fed by fissure-dyke systems and separated from Tr1 by red colored weathering band of saprolitic bole (paleosol). The latest silicic sequence phase ( $\operatorname{Tr} 2)$ with limited exposures in the region, comprises rhyolitic plug domes, rhyolitic lava flows and locally welded and unwelded volcaniclastic deposits. In places, the silicic volcanic rocks have been diagenetically altered to bentonitic clay minerals and zeolites. The youngest phase of volcanic rocks represented by the basaltic rocks in the region ( $\mathrm{Tb} 3$ ) is exposed in few outcrops along the southeastern slope of the mapped area and conformably capping the $\operatorname{Tr} 2$. It includes the basaltic flows intercalated with mafic conglomerate and tuff layers. The study area has been subjected to tensional tectonic regime throughout much of the Tertiary and extensions led to volcanism, granitic rock intrusions and formation of structural elements such as normal faults and deep joints. NW, NE, and E-W are the three major trends of faults recognized and these are related to the progressive rifting of Red Sea and Gulf of Aden.
\end{abstract}

Keywords: Yemen Volcanic Group (YVG), Taiz Area, Basalt, Bimodal Volcanism, Saber Granite

\section{Introduction}

Cenozoic Era is known for intense extrusive and explosive volcanic activities in isolated parts of the globe and development of many volcanic landforms. Across the globe, the Cenozoic volcanism is related to the movement of the lithospheric plates and largely associated with either subduction or collision tectonics. Prominent examples are the volcanism; on the Tibetan plateau in response to the India-Asia continental collision [1, 2] related to the Pacific plate subduction, back-arc spreading and corresponding marginal continental rifting in the eastern marginal part of Eurasian plate [3], in coastal California - erupted to the west magmatic arc trend related to subduction along the continental margin [4] and volcanism forms a magmatic arc running along the western margin of Sardinia and southern corse microplates in Italy [5]. However in Yemen, the Cenozoic volcanic activity in the region is related to the uplift of the Afro-Arabian plate [6] and subsequent break up into separate blocks as a consequence to the up rise of the mantle plume head called Afar plume [7, 8]. This process led to lithospheric extension and emplacement of thick bimodal volcanism with silicic pyroclastic rocks, intrusive bodies, and dyke swarms associations in Ethiopia, Djibouti, and Yemen. The huge pile of volcanic rocks on both sides of Red Sea reflect a tensional tectonic setting within continental crust associated with the opening of the Red Sea and Gulf of Aden during the early Oligocene (31 to $26 \mathrm{Ma}$ ) 
[9-13]. The $31 \mathrm{Ma}$ basaltic and 29.7 Ma silicic eruption episodes began the construction of Yemen Volcanic Group (YVG), [14] which generally overlies Late Jurassic carbonate shelf sediments called Amran Group and clastic material termed Tawilah Group. Previous studies have contributed significantly to the knowledge of the surface geology including mapping $[15,16]$ of the volcanic rocks in the region. However data on the volcanic stratigraphy and structure of the region is scanty. Little is known in detail on the Cenozoic volcanic succession in the Taiz area. This paper describes in detail the lithology and stratigraphy of early Cretaceous volcanic rocks of Yemen Volcanic Group in Taiz area thereby provides a complete record of eruption and eruption frequency over a particular time span in the studied area.

\section{Volcanology of Yemen}

The western and central part of Yemen is an uplifted highland and plateau (platform) bordered by Tihama plain in the west and Marib-Balhaf graben in the east. The stratigraphic sequence of uplifted regions includes rocks ranging in age from the Archean to Cenozoic [17,18]. The Precambrian rocks are exposed in several isolated blocks in the north and east of uplifted highland and consists of basement gneisses and island arc associations (Fig. 1)[19]. The Paleozoic (Wajid and Akbarah Formations) and Mesozoic (Kuhlan formation, Amran and Tawilah Groups) sediments rest unconformably on the Precambrian rocks [20]. As streaming lava erupted along the geological fissures, the Precambrian base and Mesozoic sediments were covered by layers of various types of Cenozoic volcanic rocks, especially in the southwestern part of uplifted area as part of Afro-Arabian flood volcanic succession. The Afro-Arabian flood volcanic succession consists of an isolated magmatic sub-regions distributed in sinuous line extending from Kenya in south to Syria in the north passing through Ethiopia, Djibouti, Eritrea, Yemen, Saudi Arabia and Jordan (Fig. 2) [14]. The succession of the volcanic sub-regions is composed of basaltic lavas, rhyolitic ignimbrites and pyroclastic fall deposits, in addition to less common basaltic pyroclastic rocks and rhyolitic lavas [21-24, 13, 14]. In Yemen, the Cenozoic volcanic group was originally named the Yemen volcanic group (YVG) $[25,18,26]$. The YVG consist of thick sequence of volcanic flows and forms the largest sub-region of Tertiary volcanic rocks in the Arabian plate. The volcanic rocks cover many thousands of square kilometers of the Yemen and extend across the Red Sea into Ethiopia (Fig. 2). The total estimated volume for the YVG is greater than $40,000 \mathrm{~km}^{3}$ of bimodal basalt/rhyolite volcanism [27], with the maximum thickness of over $2000 \mathrm{~m}$ occurring in the western part. The rocks were accumulated on an irregular pre-volcanic terrain underlain by Paleozoic and Mesozoic sedimentary rocks and Precambrian crystalline rocks. The YVG can be divided into the late Oligocene - early Miocene Yemen Trap Series (YTS), separated by an unconformity from the late Miocene Yemen
Volcanic Series (YVS) [25]. YTS consist of north-northwest-trending linear fissure systems, extending from long. $43030^{\prime}$ to $44055^{\prime} \mathrm{N}$ and lat. $13 \mathrm{o}$ to $15 \mathrm{o} 30^{\prime} \mathrm{E}$ [18] covering an area of about $40 \mathrm{~km}^{2}$.

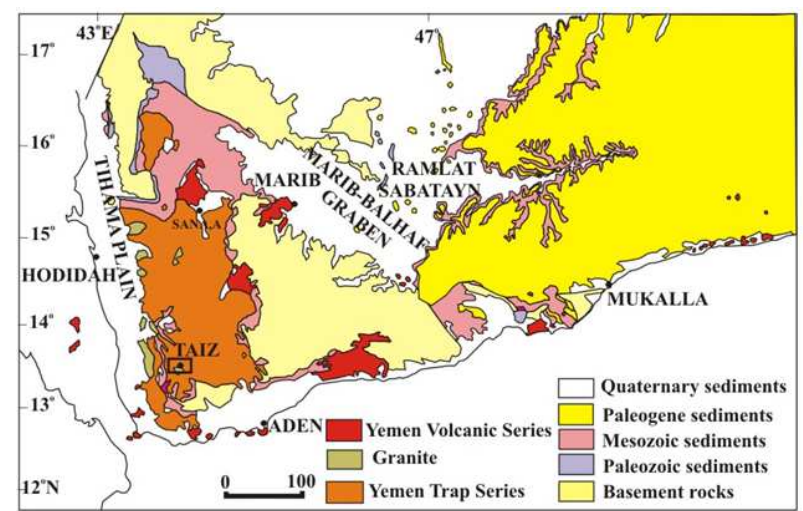

Figure 1. Simplified geological map of Yemen (modified after Garzanti et al. 2001) showing the relationship between main rock types and principal grabens. The bold-line rectangle marks the location of the Taiz area.

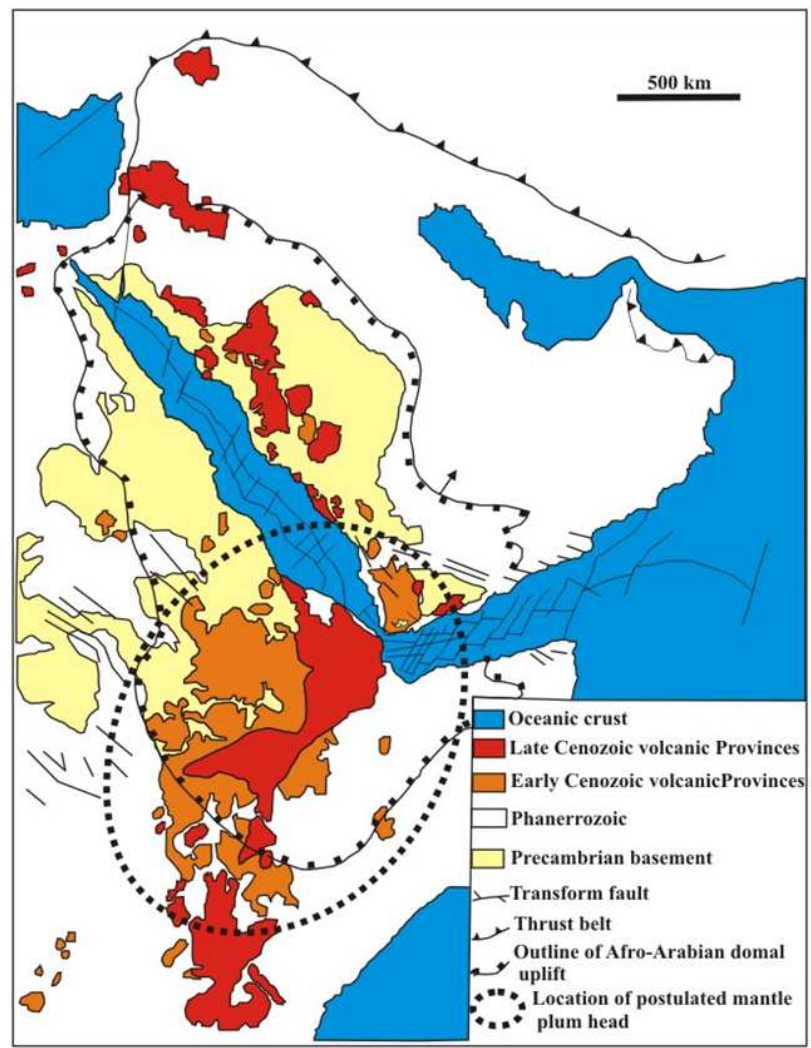

Figure 2. Simplified regional map showing distribution of Cenozoic volcanism in East African and Arabian plates related to Red Sea and Gulf of Aden opening. Note location of plume head upwelling (modified after Davidson and Rex 1980 and Ukstins Peate 2005).

YTS comprise part of a larger flood volcanic province extending into Eritrea and Ethiopia [27].The eruption of YTS took place during a period from about 31.6 to $15 \mathrm{Ma}$ $[25,28]$ although volcanic activity may have commenced as early as $40 \mathrm{Ma}[21,29,30,8,31]$. YTS eruptive activity spanned for more than 16 million years, most of the YTS flows were emplaced over a period of 5 million years from 
31 to $26 \mathrm{Ma}[27,31,13]$. During this intense period of YTS volcanism, most of the flows emplaced were of extraordinary size, commonly exceeding 200 to $2,000 \mathrm{~km}$ in volume. It covers many thousands of square kilometers [27] and traveled many hundreds of kilometers from their linear vent systems. The YVS include late Miocene-Recent volcanic rocks, which concentrated between $10 \mathrm{Ma}$ and 5 Ma [25, 28]. They are seen as more restricted and disconnected occurrences above YTS in Marib graben and sporadically along the Gulf of Aden from Bab Al Mandab to the Qusay,ar - Sayhut area and covering a total area of about $9 \mathrm{~km}^{2}$ [18] (Fig. 1). Several Suites of Tertiary plutons (named after locations at which they are exposed) intrude the rocks of volcanic sequences [32, 33] and these events have taken place during 22 to $21 \mathrm{Ma}$ [34-36]. These silicic intrusives are represented by granite, granodiorite and syenite bodies emplaced in the form of plugs, domes, dyke swarms, and composite stocks, associated with explosive ash-flow $[15,20]$. The silicic plutons are widespread but are more abundant in the south and along the western escarpment slopes of the plateau towards the Red Sea border. The plutons have alkaline or peralkaline affinity and are produced by fractional crystallization from basic magmas $[34,37,38]$.

They are coarse to medium grained, massive, and remarkably discordant showing sharp contacts with the country rocks. Angular inclusions of the basalt country rocks are also noticed at places. The largest concentration of plutons occurs along the western escarpment of the uplifted region.

During and after volcanism of the YVG, the area was subjected to block faulting and tilting. The processes of uplifting and erosion that followed led to the exposure of older rocks in the surrounding volcanic rocks.

\section{Study Area}

The Taiz area located between latitudes $13^{\circ} 30^{\prime} \mathrm{N}$ and $13^{\circ} 45^{\prime} \mathrm{N}$ and longitudes $43^{\circ} 45^{\prime} \mathrm{E}$ and. $44^{\circ} 15^{\prime} \mathrm{E}$, occupies the southern portion of a large physiographic province known as the Yemen Highlands. It comprises dominantly of volcanic rocks resting nonconformably upon sedimentary rocks dominated by Cretaceous sandstone of Tawilah Group (Kt) (Fig. 3a and b). Numerous intrusions in the form of granitic rock bodies $(\mathrm{Tg})$, mafic and silicic dykes are intruded into the sandstone and volcanic rocks. The abundant volcanic and intrusive rocks within the Taiz area suggest that the region was a magmatic center during Cenozoic extension.

Many of volcanic rocks of Taiz area are largely obscured by urbanization and surface sediment deposits. Each eruption led to extrusion of a voluminous pyroclastic-flow sheets interbedded with lava flows. The time gap between successive lava flows was conducive for the development of soil as witnessed in the occurrence of palaeosols at some places. Each group of flows exhibits distinctive lithological and stratigraphic characteristics and separated from one another by well-developed unconformities. In some places this succession becomes more elusive owing to lateral changes within the volcanic stratigraphy as a result of flow on the irregular surface, interfingering of coeval/contemporary volcanic units erupted from different centers, and pre-, syn- and post-volcanic block faulting. The majority of volcanic succession was later affected by extensive magmatism characterized by granitic intrusions and the intrusion of mafic and felsic dykes. All the volcanic rocks show signs of post-eruptive alteration. At places, alteration has resulted in the complete replacement of all primary mineral phases by secondary mineral assemblages. The effects of alteration are remarkably seen in vesicular and brecciated lava flows. Subsequent fluvial erosional processes have deeply dissected the volcanic field providing excellent exposures of several volcanic rocks. The best exposures are seen along road cuts, quarries and stream valleys, where outcrops are large and fresh.

\subsection{Cenozoic Geology of Taiz Area}

The Cenozoic volcanic stratigraphy of Taiz area is composed of relatively younger rocks resting on Cretaceous sandstone (Tawilah Group). The sequence is rocks represented by a series of mafic and silicic rocks ranging in age from the Oligocene to the lower Miocene [18] (Fig. 3a). The complete stratigrahic section is divided into five units (Fig. 3b), with well defined boundaries, representing different volcanic eruptions. From base to top the Cenozoic volcanic section in the study area comprises: (1) lower mafic sequence (Tb1), (2) lower silicic rocks sequence $(\operatorname{Tr} 1),(3)$ middle mafic sequence (Tb2), (4) upper silicic volcanic rocks (Tr2), and (5) upper basalt flows (Tb3). The stratigraphic section includes several important sediments containing abundant volcaniclastic components derived from surrounding volcanic rocks.

\subsubsection{Lower Basalt Sequence (Tb1)}

Stratified and massive on a minor scale, basaltic lavas of several hundred meters thick, frequently extruded primarily through the feeder dykes paralleling the axis of the Red Sea. constitute the lower basalt sequence (Tb1) of the Taiz area.

It is most voluminous rocks of the YVG in Taiz area that rest unconformably on an irregular topographic surface of Tawilah Group. The unconformity can be seen on the western rim of the mapped area (Fig. 4a). Contact with the underlying rocks is generally obscured in most part of the studied area, but the upper contact with lower silicic rocks is well exposed and sharp, commonly irregular in most of the localities. At places, the Tb1 flows occur as cap above granitic rocks of the Saber Pluton. (Fig. 3a) shows the flow that is forcefully intruded by Saber granite pluton with no effects of thermal metamorphism. The thick stack of Tb1 pile (cumulative thickness of about 600 meters) comprises either multiple or single cooling flow interbeded with centimeter to several meter thick volcaniclastic basic rocks of various kinds. Due to differential intensity of weathering, the colour of basaltic lavas and their volcaniclastic intercalations varies from dark gray in fresh surface, to 
chocolate brown or dark reddish brown, often hampering identification of the actual rock composition in weathering surface. These rocks consist of semiconsolidated deposits of mafic ash, air-fall scoriaceous deposits and tuffaceous sediments. Many glass fragments, not greater than $\mathrm{I} .5 \mathrm{~cm}$ are observed in the matrix of the pyroclastic units. The Tb1 flows exhibit well developed colonnade and entablature structures with low proportion of vesicles. The lower (basal) entablature zone commonly grades upward into a colonnade in some flows.

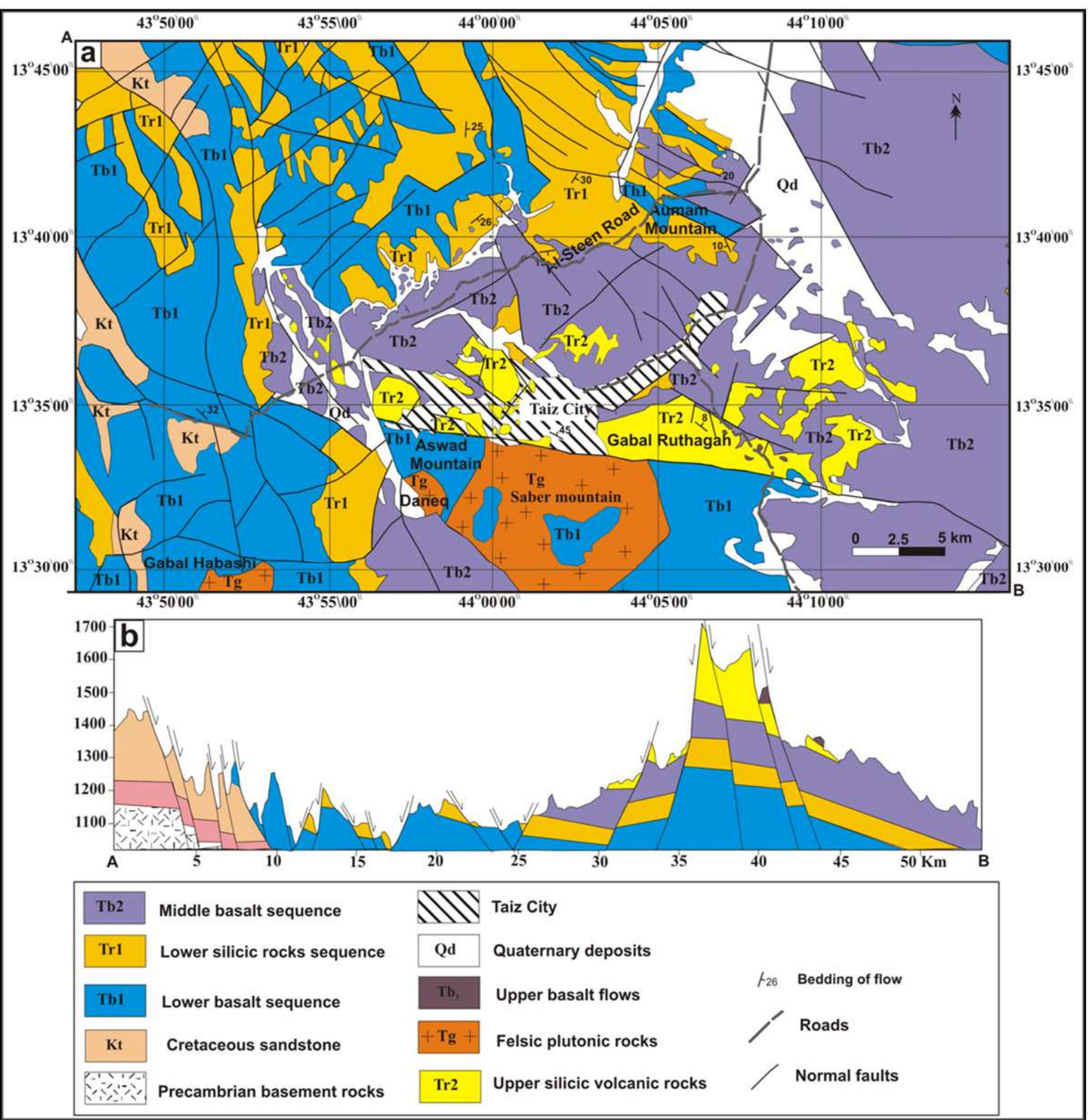

Figure 3. (a). Geologic map of the study area, indicating rock types and major faults (modified after Kruck and Schaffer 1991). (b): northwest-southeast cross section through the study area, illustrating relationship between rock units and normal faults.

The rocks are frequently strongly fractured with fracture spacing from a few to $\sim 15 \mathrm{~cm}$. The calcite veins are occasionally present. Texturally, the lower basalt flows consist of two different varieties; (1) the more widespread fine grained nonporphyritic, locally containing vesicles and amygdules of secondary minerals (Fig. 4b), (2) porphyritic, where the plagioclase and/or olivine phenocrysts in some specimens are distinguishable megascopically. Plagioclase phenocrysts are euhedral to subhedral, zoned and occasionally clustered into aggregates thus exhibiting glomeroporphyritic texture and some phenocrysts define a flow fabric foliation. Larger six-sided olivine phenocrysts in the fine groundmass are typically highly fractured with some zoning (Fig. 4c). These are often altered at their rims and fractures into iddingesite. Olivine is present in some thin sections and absent in others. The fracturing and breakage of some phenocrysts suggest turbulent transport. Euhedral pyroxenes are also present as phenocrysts and in the groundmass. In places and particularly in the northeastern part of the map area, the $\mathrm{Tb} 1$ are scoriaceous and vesicular and include pyroclastics beds and lenses. The brecciated and vesiculated zones are visible along fault 
plane. Mineralogy of some dyke rocks are similar to basalt flows of $\mathrm{Tb} 1$ and the dykes cut the sequence of older rocks in the area and may have served as feeders for the mafic flows within the sequence (Fig. 4d). The weathering and alteration of rocks toward upper contact zone hamper the study of volcanic structures at the top of the basalt flows.
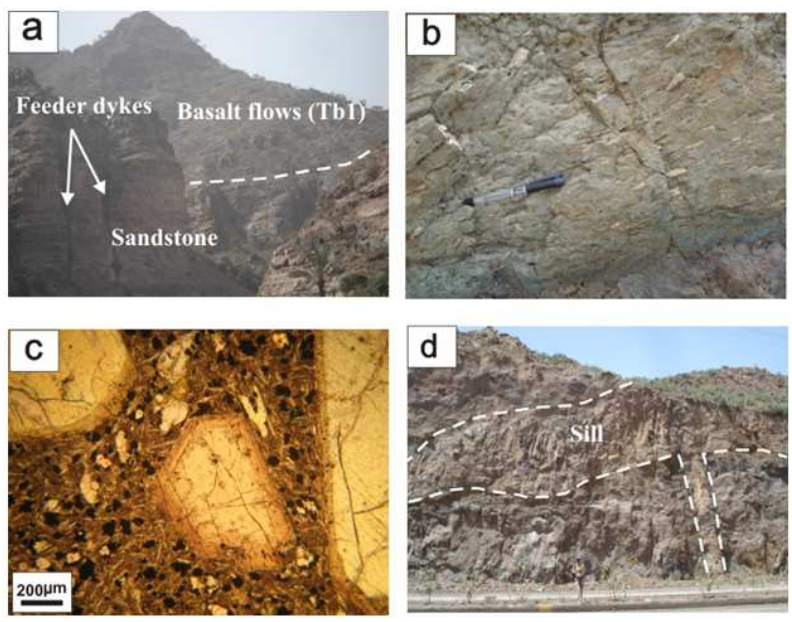

Figure 4. (a) A view showing Tawilah sandstone (lower part of the photo), unconformably overlaid by basalt flows (upper part of the photograph). Note swarms of basic dykes forming feeder to basaltic lavas of the Lower basalt sequence,(c) Photomicrograph of olivine phenocrysts showing zoning, coating in a finer groundmass under normal light,(d) View of $\sim 1 \mathrm{~m}$ wide feeder dyke of basalt connecting with $4 \mathrm{~m}$ thick sill sandwiched between two basalt flows.

\subsubsection{Lower Silicic Rocks Sequence (Tr1)}
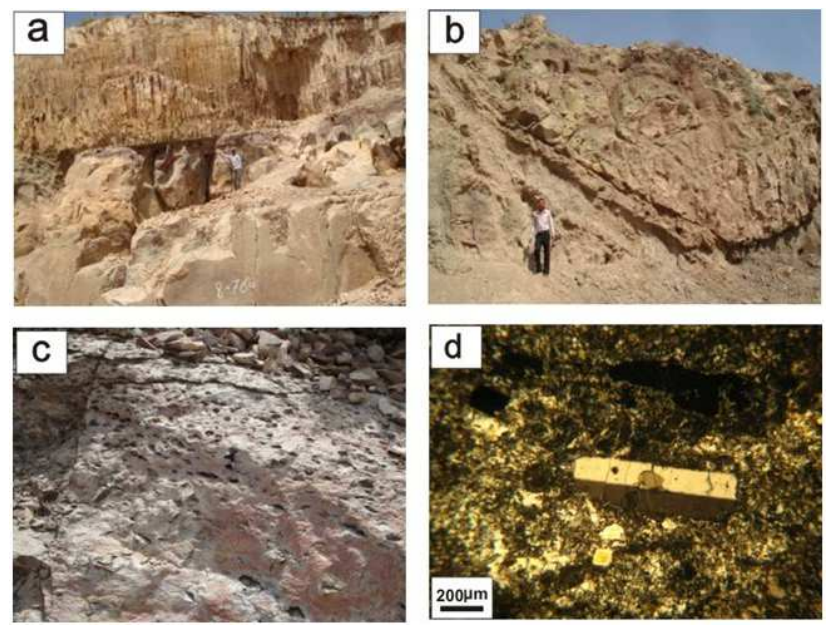

Figure 5. (a) View of rhyolite lava flows with well-developed colonnade columnar jointing in the upper flow, (b) View of an infilled channel that has cut down through volcanic tuff.(c) Highly vesicular upper part of the rhyolite flow,(d) Photomicrograph of sanidine phenocrysts in a finer ground mass (crossed nicols).

The Tb1 sequence is overlain by an extensive section of silicic volcanic rocks ( $\operatorname{Tr} 1)$ forming plateaus and rarely small hills consisting of varied assortment of lithologies including rhyolite flows, ignimbrites, welded ash, volcaniclastic breccia, and random pumice and obsidian. The higher amounts of volcaniclastic rocks indicate that initially volcanism of silicic volcanic rocks was more explosive. The Tr1 either rest directly on the basaltic rocks or locally upon a $0.5-5 \mathrm{~m}$ thick clastic sediments and paleosol. Contacts with the underlying and overlying basalt and /or clastic sediments are sharp but slightly irregular. The $\operatorname{Tr} 1$ varies in their appearance from multi-sheet stratifications to domal mountains and hills with elevation up to $200 \mathrm{~m}$ from the local base level and extends to several kilometers (Fig. 5a). These rocks at places extend through canyons (Fig. 5b). The tabular bedding are interpreted to represent ash-fall deposits. Some exposures of rhyolite flows display colonnade shrinking joints and often form a regular pattern of parallel discontinuities (Fig. 5a). The jointed rhyolite has been quarried for local building purposes. It exhibits spheroidal, exfoliation, blocky and cavernous weathering features. The flow beds occur in between two pyroclastic layers and can be subdivided into three parts based on vesicle distribution patterns. The basal part is massive that noticeably lacks vesicles and is irregularly jointed. It is overlain by about $2 \mathrm{~m}$ thick bed containing few numbers of large ellipsoidal vesicles. This bed is overlain by about $1 \mathrm{~m}$ thick bed containing vesicles ranging in size from a few millimeters to several tens of centimeters (Fig. 5c). These vesicles and cavities are sometimes filled by secondary alteration minerals such as calcite and chalcedony. At places, the vesicles are filled by chalcedony forming thunder eggs structures. The size of concentric or star-shaped thunder eggs varies from $1 \mathrm{~cm}$ to $8 \mathrm{~cm}$. The ryholite lava flows are generally phyric containing phenocrysts of quartz and sanidine, commonly fractured or fragmented, suggesting that they were broken during emplacement (Fig. 5d). Quartz and feldspar phenocryst, commonly are clustered in aglomeroporphyritic texture. Flow-bands clearly indicate an extrusive mode of emplacement. The rhyolite quarry, located at Al-Masnah village along Al-Steen Road, about $15 \mathrm{~km}$ north of the Taiz city, from bottom to top consists of sequence of alternating layers as follows: (1) whitish yellow of welded pyroclastic rhyolite, ranging from fine-grained ash to lapilli, (2) highly vesicular, whitish yellow pumice. (3) blood-red, massive, fine grained, highly welded ignimbrite with flow banding structure and (4) reddish yellow, colonnade columnar jointing rhyolite. Contact relations between the pyroclastic rocks and rhyolite indicate that they were emplaced at least in part simultaneously. The volcaniclastic rhyolites show both vertical and lateral diversity in terms of color, pyroclast lithology and degree of alteration within individual units. The basalt fragments generally occur as dark brown, round spots or elongated fragments within the flow, but also larger, sheet-like fragments are occasionally observed. Tuff sheets are exposed at different levels within silicic volcanic rocks, more commonly near the bottom than at the top of the sequence. A relatively persistent zone of volcaniclastic breccia is sandwiched and found at about $100 \mathrm{~m}$ below the top of the horizon. Tuff sheets in most cases rests with apparent conformity and is essentially coextensive with the underlying and overlaying rocks. The tuffs are mostly welded, felsic, creamy white to light gray 
in color and locally occur as reddish rock. In some localities tuff sheets tend to weather into unconsolidated soil. They are composed of angular mineral grains in a fine fragmental matrix. Much of the tuffaceous material in this unit contains lithic fragments (up to $1 \mathrm{~m}$ in diameter) derived from older local units.

\subsubsection{Middle Basalt Sequence (Tb2)}
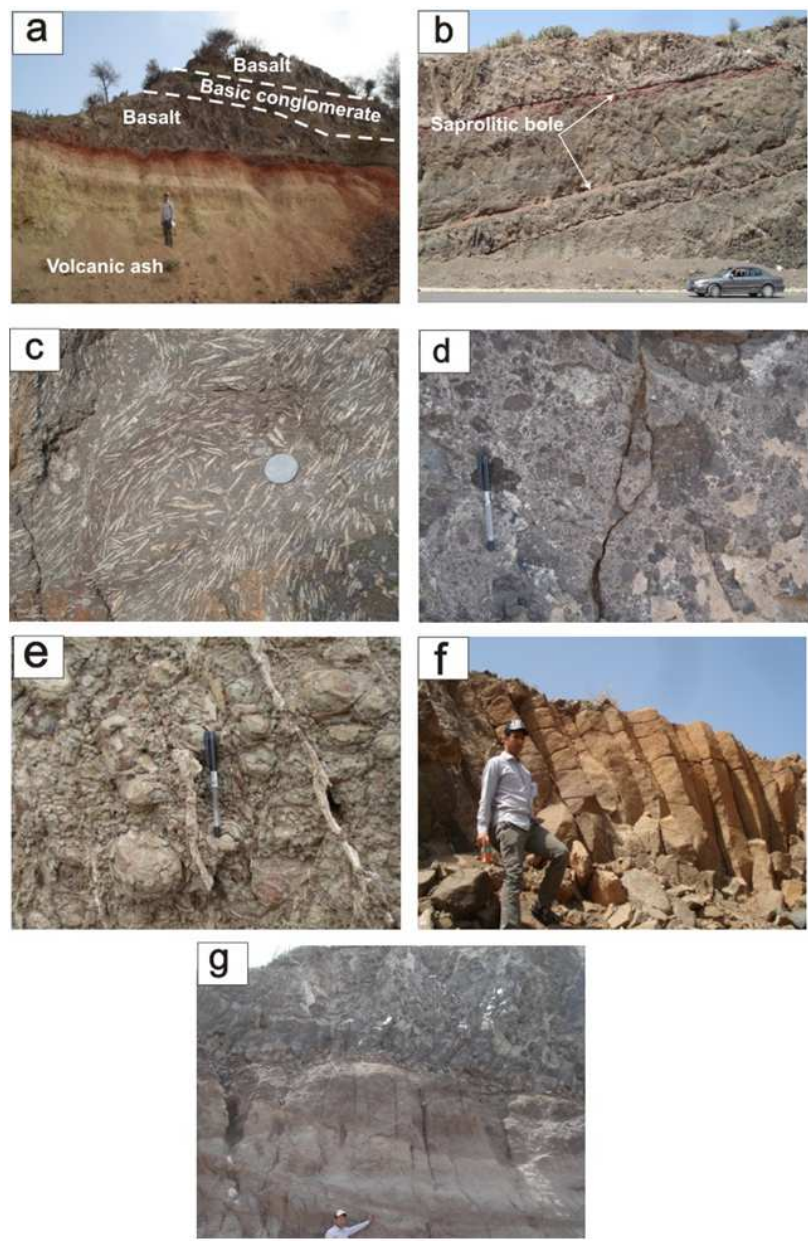

Figure 6. (a) View of sharp contact between acidic volcanic ash (lower) and middle basalt sequence, (b) Four simple sheet lava flows of Tb2, note the thin saprolitic bole at the top of each basalt flows, (c) Flow structure in basalt (d) View of volcaniclastic conglomerate with porphyritic basalt fragments in fine grained tuff matrix, (e) View of volcanic bombs embedded in fine-grained basalt, (f) Colonnade columnar jointing, (g)The entablature columnar jointing in lower flow of Tb2.

Middle basalt sequence (Tb2) stands out in marked contrast to the much thicker flows of the Tr2 sequence (Fig. 6a). It consists of at least four flows, which vary in thickness from 1 to $20 \mathrm{~m}$ (Fig. 6b). At the Al-Steen road, the total thickness of $\mathrm{Tb} 2$ is at least $100 \mathrm{~m}$. Entire sequence of $\mathrm{Tb} 2$ thins westward. The basal contact is sharp and planer and overlies an extremely weathered flow top of the underlying flow Tr1 (Fig. 6b). This is marked by a reddened weathering band $\sim 50 \mathrm{~cm}$ known as saprolitic bole (paleosol). The red color indicates that the iron in the rock is oxidized. In some places, the weathering bands grades downward from red mudstone into debris zone dominated by basalt core stones produced from underlying flow. In most hills, Tb2 flows cap stratigraphic unit of YVG. These basaltic rocks are mainly aphyric, although plagioclase and olivine porphyritic types are also commonly observed (Fig. 6c). N-S to NW-SE trending feeder dykes located along Al-Steen road, appear to be a large vent of basalt flows. The volcaniclastic conglomerate measuring up to $6 \mathrm{~m}$ thick intercalated between two basalt flows (Fig. 6a) is observed at Al-Gibarah village. The volcaniclastic conglomerate is poorly sorted clasts consisting of angular, subangular, to subrounded vesicular/ amygdaloidal to non-vesicular basalt lava clasts, and the latter range in size from those of pebbles and to cobbels. (Fig. 6d). Volcanic bombs are observed within some exposures exhibiting vesicle-poor cores whilst having highly vesicular margins (Fig. 6e). The columnar jointing structures known as colonnade and entablature are common structures observed in Tb2. Colonnade structures commonly occur in the upper part of basalt flow, and consist of relatively well-formed $10-50 \mathrm{~cm}$ basalt columns which are typically oriented perpendicular to the base of the flow (Fig. 6f). The entablature zone exhibits small (30 to $10 \mathrm{~cm}$ in diameter) irregular columns, which may form radiating or fanning patterns, or otherwise deviate from an orientation perpendicular to the base of the flow (Fig. 6g).

In many basalt flows, entablature grades upward into an upper colonnade zone. Hollow spherical to oblate geodes occur in large quantities within $\mathrm{Tb} 2$, particularly in the northeastern part of the study area. The geodes range in size from a few to tens of centimeters, have an outer shell of chalcedony, followed inwards by white color lined agate and finally euhedral, colorless quartz and /or calcite.

\subsubsection{Upper Silicic Volcanic Rocks (Tr2)}

A well-preserved upper silicic volcanic rocks $(\operatorname{Tr} 2)$ were found in fault contact of Saber pluton in the form of isolated domal mountains and plugs, rising to an altitude of about $250 \mathrm{~m}$ above local base level. At places such as Gabal Ruthagah and Adenah, Tr2 overlies Tb2 which can be laterally traced for several kilometers. The domes occur in the forms of conical, hemispherical and nearly flat tops, with varying slopes. The slope regions consist of different size blocks, up to several meters in their diameters (Fig. 7a). The outer surfaces are relatively rough owing to fracturing and exfoliation phenomena. The rhyolitic rocks display lateral changes in their colour and hardness due to the changes in their proportion of pyroclastic materials and rock texture. The pyroclasts-poor rhyolite is characterized by abundant feldspar and quartz phenocrysts in finegrained matrix in comparison to pyroclasts-rich rhyolite. A number of well-defined ridges and knobs of pyroclasts-poor rhyolite observed at Gabal Al-Birarah are accentuated by weathering. Some ridges with medium- to coarse- grained massive rhyolites exhibiting spheroidal weathering and feldspar phenocrysts may represent subvolcanic dykes. In some places, as seen in the road cut below Gabal Al-Garah ridge, a clastic immature sediment 
zone (Fig. 7b) separates Tr2 from Tb2. This zone may probably represent quiescent period of volcanic activity during which rock weathering and erosional processes lead to the formation of poorly bedded sedimentary horizons. The presence of this clastic unit in some localities and disappearance in others may be attributed to the significant variation in the topography of older basalt sequence.
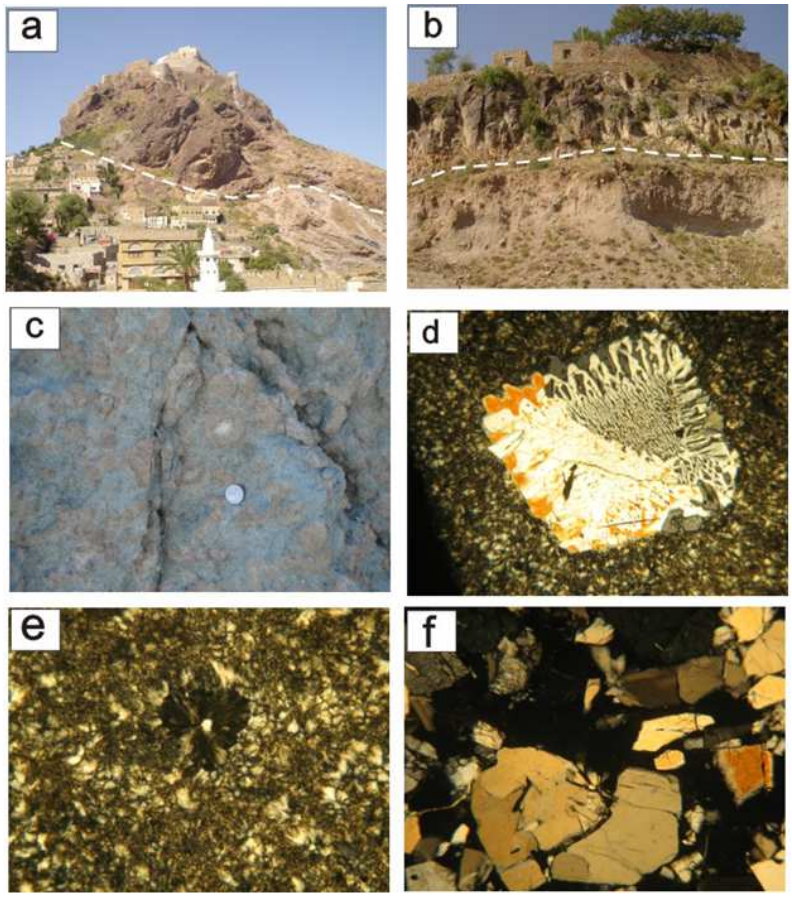

Figure 7. (a) View of southeast side of Cairo Castle cone, composed of mixtures of rhyolite lava flows(upper) with ignimbrite and tuffs(lower), (b) View showing Tr2 rhyolite (upper part of the photo), underlain by mixture of clastic, immature sediments (lower part of the photo), (c) View of accretionary lapilli in fine grained tuff, Thoapat area, (d) Photomicrograph showing granophyric texture, consisting of two zones of quartz which fill most of an original simple twinned K-feldspar phenocryst (Crossed nicols), (e) Photomicrograph showing spherulite texture nucleated around fine grain (Crossed nicols), (f) Photomicrograph of welded pyroclasts consisting mainly of altered quartz and feldspars..

Topographically elevated parts are the probable sources for these coarse clastic sediments. The lower contact of $\operatorname{Tr} 2$ over the underlying $\mathrm{Tb} 2$ at Gabal Kilabah shows a red coloured zone which possibly represent a hydrothermally altered lateritic - horizon. Occurrence of erosional surface between the rhyolitic rocks and underlying basalt flows implies discontinuity of eruption of rhyolite and basalt. The Tr2 show varying colors including white, yellow, pink and greenish grey. In the quarries and road cuts, located in different localities within Taiz city, the Tr2 comprises alternating layers or beds of welded and unwelded volcaniclastic units, varying in bedding character, grain size (ranging from fine-grained ash to lapilli), and depositional structure. Volcaniclastic units contain different sizes of lithic rhyolite, obsidian and basaltic clasts pointing to the violent explosive nature of the silicic volcanism. In many cases, pyroclastic flow deposits are internally massive or stratified. The high concentration of accretionary lapilli in fine grained tuff, bedded with white to light gray, friable, fine grained tuff as noticed in Thoapat area indicates that water was occasionally present in the eruptive cloud in subaerial deposition environment (Fig. 7c). Microscopic study of the flow revealed the occurrence of the Tr2 as altered rock. A variety of textures have been observed in the the rhyolitic flows including porphyritic, granophyric and spherulitic. The porphyritic textured rhyolite contains phenocrysts of sanidine, plagioclase, and quartz embeded in highly altered fine grained groundmass. The groundmass is locally vitrophyric but generally devitrified. The granophyric texture radiates out from feldspar grains (Fig. 7d). Spherulites occur mostly as isolated and frequently nucleated on existing fine grains (Fig. 7e). The volcaniclastic units are made of detritus consisting of mineral grains, rock fragments and glass shards. Quartz and feldspars are common grains occur as irregular angular and rectangular shaped grains (Fig. 7f). In places, the silicic volcanic rocks have been altered to bentonitic clay minerals and zeolites particularly in volcaniclastic units where the rhyolitic rocks are highly fractured. The presence of younger rhyolite dykes dissecting $\operatorname{Tr} 2$ suggests the extrusion of lava in the form of series of domes and flows rising more mainly along fractures.

\subsubsection{Felsic Plutonic Rocks (Tg)}

Felsic plutons of varying dimensions are found intruding into the older volcanic rocks ( $\mathrm{Tb} 1, \mathrm{Tr} 1, \mathrm{~Tb} 2$ and $\mathrm{Tr} 2$ ) in Taiz area. Saber Mountain with an altitude of 3000 m. a.s.l. exposed in the southern border of Taiz city represents a largest pluton. Some of the smaller plutons viz., Daneq and Gabal Habashi rise to altitudes of 1650 and 2300 m. a.s.l. Other unnamed small masses or dyke-like intrusions such as those at Wadi Al-Dahi (40 m thick) are considered as small offshoots sent from the main pluton into the adjoining volcanic rocks.
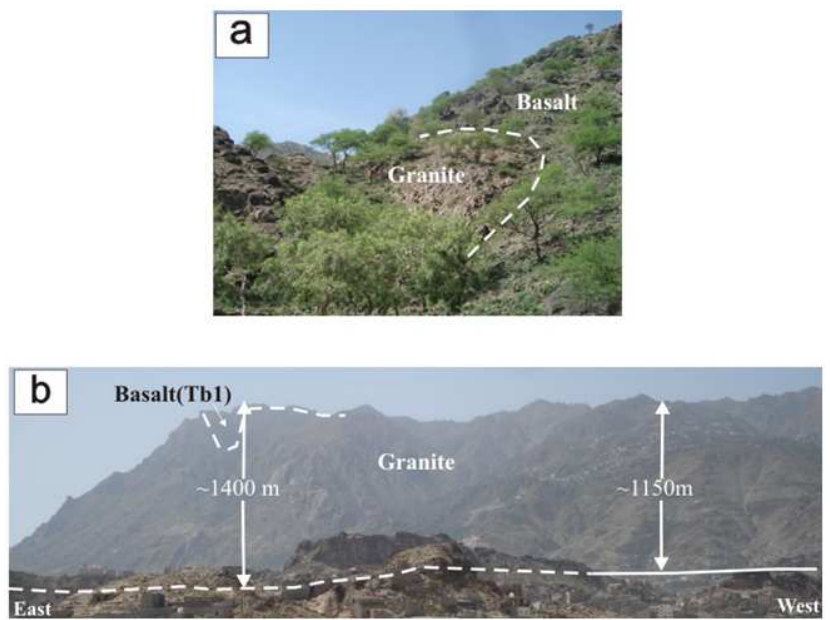

Figure 8. (a) View showing sharp contact between granite and older basalt (Tb1). (b) View of Saber mountain escarpment showing granite crowned by older basalt and in fault contact with rhyolites.

Obviously these Tertiary granite plutons represent the coeval magmatic phase with the different intrusions, 
located in the western part of Yemen. Plutons vary in composition from alkali granite to syenogranite [15, 38], however to simplify the terms for this study, all these variable compositions are referred to as "granites". The granite plutons occur as stocks, typically show sharp and discordant contacts with adjoining volcanic rocks, indicating intrusion into brittle and cooler crust (Fig. 8a). Both Saber and Daneq plutons have oval shape, elongated in $\mathrm{E}-\mathrm{W}$ direction for a distance of 9.5 , and $2.2 \mathrm{~km}$ respectively, with elevations ranging up to $1.4 \mathrm{~km}$ from the local baseline and corresponding to a total surface area of approximately $70 \mathrm{~km}^{2}$ (Fig. $8 \mathrm{~b}$ ). The granitic rocks are grayish white in colour, massive, locally strongly fractured and spheroidally weathered and occur in the form of large blocks. The blocks have undergone chemical weathering as evidenced by the formation of clay minerals at the margins. The grain size of granites ranges from medium to coarse. The radiometric dating carried out on the Tertiary granites have yielded an intrusion age of about $21.9 \pm 0.7 \mathrm{Ma}$ [33].

\subsubsection{Upper Basalt Flows (Tb3)}

The Upper basalt flows (Tb3) are the youngest Tertiary volcanic rocks which are confined to the southeastern part of the mapped area in the form of a few isolated small outcrops, conformably capping the $\operatorname{Tr} 2$ (Fig. 9a). It includes the basaltic rocks that makes up the predominant flows intercalated by andesite, mafic conglomerate and tuff layers or as dykes cutting across the volcanic rocks and granite intrusions (Fig. 9b). In the Naqil Al-Epil area, the Tb3 basalt interfingers with the underlying $\operatorname{Tr} 2$ rhyolite. Absence of erosional surface between basalt lava flows and pyroclastic units suggest that there was no major hiatus during the formation of the volcanic center.

Microscopic observations show that most of the $\mathrm{Tb} 3$ are fine grained, nonporphyritic and rarely contains plagioclase phenocrysts (Fig. 9b).

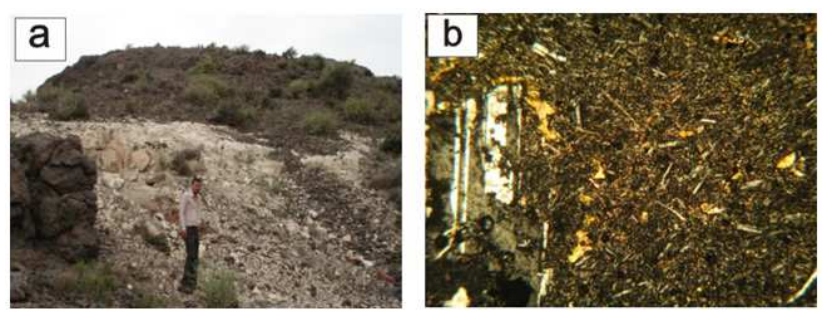

Figure 9. (a) Top of Naqil Al-Epil hill exhibiting the interlayering of volcanic tuff and basalt lava flows (Tb3). (b) Photomicrograph of fine grained basalt containing plagioclase phenocrysts.

\subsubsection{Dykes and Sills}

Multiple generations of basic and silicic dykes show NW-SE, NNW-SSE, NE-SW and E-W orientations and have intruded into Tawilah sandstone and volcanic succession in Taiz area. It appears that the intrusive material fills a set of subvertical tensional fissures produced during the rifting process. The close spatial relation of various dykes with five volcanic successions described above indicate that the dykes are injected during different phases coeval with mafic and felsic igneous products. Their relative ages can be established from cross-cutting relationships between them. Sometimes the dykes are extremely difficult to distinguish from similar rocks, but in fresh exposures, as in road cuts and quarries, the dykes are readily visible because of their strong contrast in color and texture with the similar volcanic rocks which they intrude (Fig. 4d). The dykes can have a planar form or very irregular margins. The mafic dykes are contemporaneous with $\mathrm{Tb} 1, \mathrm{~Tb} 2$ and $\mathrm{Tb} 3$. These dykes are dark gray, porphyritic to fine-grained, sometimes contain plagioclase and olivine phenocrysts. The dykes are generally thin $(<2 \mathrm{~m})$, although the dykes exceeding ten meters are also observed in Hagdah and Al-Manakh Mountains. Dykes appear as cliffs or dip steeply in NNW to NE directions and appear to be controlled by rifting joint or fault trends. The contact is sharp and no visible chilling effects are observed especially in thin dykes. Some dykes preserve flow fabrics. Mafic dykes arranged in parallel to subparallel groups representing "swarms", intrude cretaceous sandstone and volcanic succession in the study area. In some localities, the columnar sheet basalt in the succession, has not been extruded as lava, but injected between the basalt flows as subhorizontal basaltic sills (Fig. 4d). The sills are fed and linked by dykes (Fig. 4e). Few meters long horizontal to subvertical offshoots originated from several mafic dykes are seen. These offshoots are commonly found in the dykes emplaced adjacent to the sandstone.

The silicic dykes intruded into the volcanic succession show dominant orientations along N-S, NNE-SSW and NW-SE directions. The dykes are 1 to $12 \mathrm{~m}$ thick, although the thicknesses of individual dykes are seldom constant even for a short distance. Many of them extend to several kilometers. Some rhyolite dykes form prominent, blocky ridges, and others are less resistant to weathering than the surrounding rocks and form deep trenches, where they show a prominent horizontal columnar jointing, polygonal columns mostly being pentagonal or hexagonal in cross sections. These dykes are white, yellow, and greenish white to reddish in color, generally distinctly porphyritic with feldspar phenocrysts. Many aplitic dykes were observed cutting the volcanic succession around Saber granite pluton, and these do not cross cut granite thus indicating them to be off shoots from a feeder pluton.

\subsection{Structures}

Geological map of Taiz area (Fig. 3a) reveals that the distribution of the various rock types and geomorphic features appears to be significantly influenced by NNW-SSE, NE-SW and E-W trending normal faults created by extension associated with the opening of the Red Sea and Gulf of Aden [e.g.(39,40)]. The marking of the spatial distribution of the faults was initially achieved by tracing linear elements on ETM+ satellite image and earlier geological maps. Ground checks were made wherever necessary. The faults have linear or curved shape, with terminal segments showing a systematic tendency to change their strike directions. Cross-cutting relationships between 
the two or more of normal faults display that the NW-SE to NNW-SSE trending fault system is relatively older than the E-W faults system. The faults have a low to high vertical displacement, characterized by the presence of fault scarps, dividing the rocks of the study area into tilted blocks that have relatively steep slopes toward east and north. Movement took place on a vertical or inclined surface but assumed a listric form in the underlying rocks. The listric normal movement caused the rotation of the hanging wall block (Fig. $10 \mathrm{a}$ and b). The magnitude of the throw varies and the maximum vertical displacement is seen to the north of Saber pluton wherein the throw, on the eastern face, measures about $1100 \mathrm{~m}$ (Fig. 8b). The grinding between the two fault blocks caused the rock to break up and become less resistant which upon erosion, led to the formation of the trenches. The fault blocks are commonly obscured by weathering and wadi sediment accumulations but where visible, they show cataclastic texture. The fault gouge, breccias (consolidated and unconsolidated forms) and slickensides, which carry striations on their surface, are the major indicators observed along fault-line scarps, which can be distinguished from the host rock on the basis of texture and color (Fig. 10c). The fault scarps on volcanic rocks generally provide the most reliable indications of relative age of fault formation, whereas the fault scarps on granite rock are degraded owing to erosion. The most obvious structural feature of the area is the moderately tilted volcanic sequence that dips in several directions, dominantly towards east, defining different trends of normal faults (Fig. 3b). The multiple downthrows of faults toward each other at several places form small grabens (Fig. 10d).

The first major fault system trending in NW-SE to NNW-SSE direction, extends parallel to the SW Saber master fault. The fault system consists of a series of parallel faults defining mountains and depressions topography. This direction corresponds to the volcanic emplacement, and Red Sea rifting. From the geological map (Fig. 3a), it is evident that the western margin contains stratigraphy that cannot be recognized in the east which is controlled by NW-striking faults. The second major fault trend is parallel to the southeast Saber master fault. This fault system bounds the Saber mountain to the south east and run in the NE-SW direction parallel to the Gulf of Aden axis. The third trend of normal faults is parallel to the major fault located North Saber mountain, which extends several kilometers with general E-W to ESE-WNW strike. They dip either to the north or south. Many of these faults are well exposed and contain well-developed striate and kinematic indicators. Several of smaller offset synthetic and antithetic normal faults, most commonly exposed in the central part of the mapped area, often produce several small half-grabens. Figure 10a shows good examples of such antithetic normal faults in the central part of the area. The extensive dip slopes and tilt direction of the rhyolites toward north at northern border of Saber mountain may be related to the master fault downthrown mostly on its north side, here named the North Saber master fault. Displacement along this fault decreases westward where the rhyolite volcanic sequence is in direct contact with lower basalt sequence.
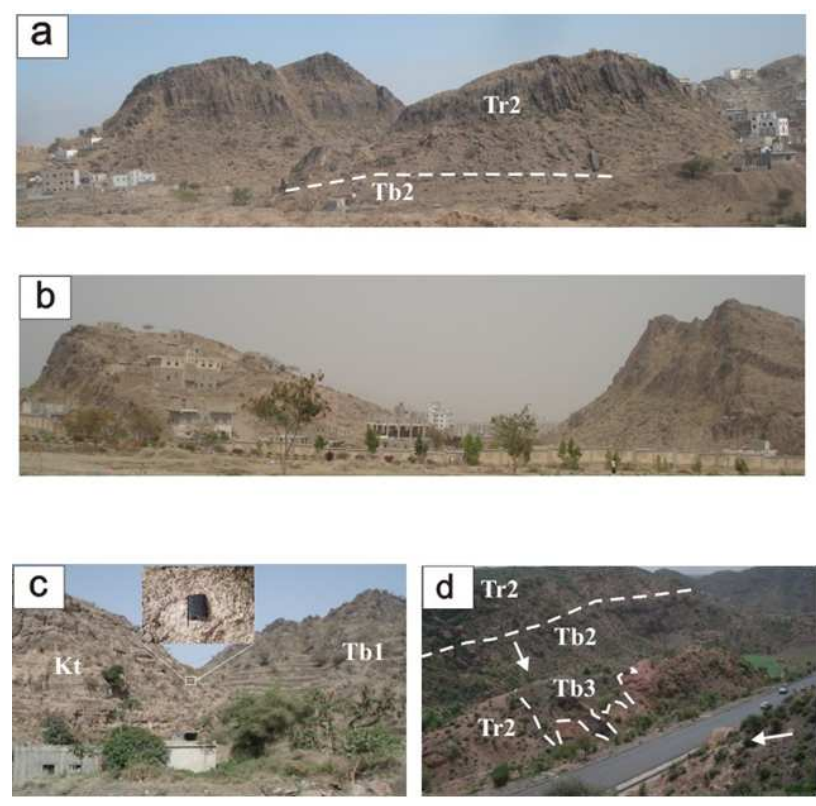

Figure 10. ( $a$ and b) Rhyolite dome dissected by two normal south-dipping antithetic listric faults parallel to the Saber master fault causing rotation of the hanging wall block, (c) View shows normal fault separating the Tawilah sandstone (in the left) and the Tb1 basalt (in the right). The inset show fault breccia and gouge along a normal fault, (d) View looking east, from the top of Naqil Al-Epil shows two opposite displacement normal faults forming small graben. Dotted lines show conformable contacts between volcanic units.

\section{Conclusions}

The present study covers Cenozoic stratigraphy and structure of Taiz area of Yemen based on field geology. Magmatism in the study area is related to the continental rifting and break up processes associated with Afar mantle plume. The study provides for the first time the volcanic stratigraphy and structure of the Taiz area which have important implications concerning the geodynamics and magmatic evolution of the rift.

The excellent exposure of the Tertiary magmatic rocks provides an unique opportunity to study different volcanic succession units and related intrusions in the Taiz area. Detailed studies carried out on the stratigraphy and structures in Taiz area led to the following conclusions:

1. The study area in and around Taiz city is considered to be a part of an YVG, where the basalt-rhyolite association and accompanied volcaniclastic units have formed the major mountainous backbone of the area. The bimodal distribution of silica is attributed to systematic variation in melting depth over time.

2. The past and present studies reveal that the volcanic rocks in Taiz area closely resemble in their extension and thick accumulation to the volcanic products of an intra-continental rift setting. In this setting large effusive volcanoes extruded lavas that have been inter-fingered and injected in the forms of plutons, dykes and sills. 
3. Based on the field, petrographic and radiometric evidences, it can be deduced that the volcanism in Taiz area was active for more than $10 \mathrm{Ma}$. The sheet-like distribution of volcanic rocks indicates that the entire succession is an accumulation zone erupted through three mafic and two silicic phases of volcanism instead of individual volcanic edifices. Early volcanism was dominated by the effusion of mafic lava flows (Tb1), beginning at about 31 Ma followed by silicic volcanism $(\operatorname{Tr} 1)$ at about $29.7 \mathrm{Ma}$. Later eruptions of voluminous mafic and silicic lava flows (Tb2 and Tr2 respectively) continued till the emplacement of Saber granite which is estimated at about $21 \mathrm{Ma}$, followed by Tb3 mafic eruptions. The stages in the evolution of volcanism and associated landforms are schematically depicted in Fig. $11 \mathrm{a}-\mathrm{g}$.

4. Each eruption started with the formation of pyroclastic deposits and ending with the relatively quiet effusion of magma to form lava flows or domes.

5. Source vents for the lavas especially basaltic lavas are difficult to recognize, but abundant dikes suggest that many lava flows may have been erupted from fissures rather than spot sources.

6. The common interbedding of basalt and rhyolite indicates that such magmas were available at the same place contemporaneously. Field observations support the view that two magmas of highly contrasting compositions coexisted at least for limited periods and were erupted sequentially throughout the geologic time.

7. In the study area, occurrence of pillow lava is no where reported. Further, the presence of columnar jointing and weathered flow tops are good signs to infer the existence of subaerial conditions during the eruption history of the Taiz lavas and the accumulation of volcanic products.

8. The volcaniclastic successions identified in the Taiz area documents a complex eruption, transportation and depositional history, where primary pyroclastic units interbedded with eruption flows show saprolitic bole and weathered flow tops with uncommon inter-eruption epiclastic succession. The large volume of pyroclastics in the entire Taiz succession is interpreted to be deposited by debris flows produced by repeated pyroclasts flow eruption. The rare occurrence of non-volcanic debris in most of volcaniclastic rocks indicate that the source area of these debris flows is volcanic in origin.

9. The volcanic phases are intermittent with quiescent periods during which rock weathering processes and redeposition, led to the formation of poorly bedded sedimentary horizons.

10. Final stages of igneous activity involved the emplacement of Saber granite plutons and small intrusive bodies at about $21 \mathrm{Ma}$.

11. Multiple generations of dykes, normal faults and deformed volcanic succession show very wide variation in orientation, but with a bias in favor of NW-SE and NE- SW trending faults and dykes.

12. The mapped area is characterized by the focus of volcanic centers related to the rhyolite volcanic sequence. Evidence for this is found in the form of columnar jointing, rhyolite domes, abundant pyroclastic material and rhyolite dykes cutting lower basalt sequence, and the remarkable change in the thickness of volcanic sequence.
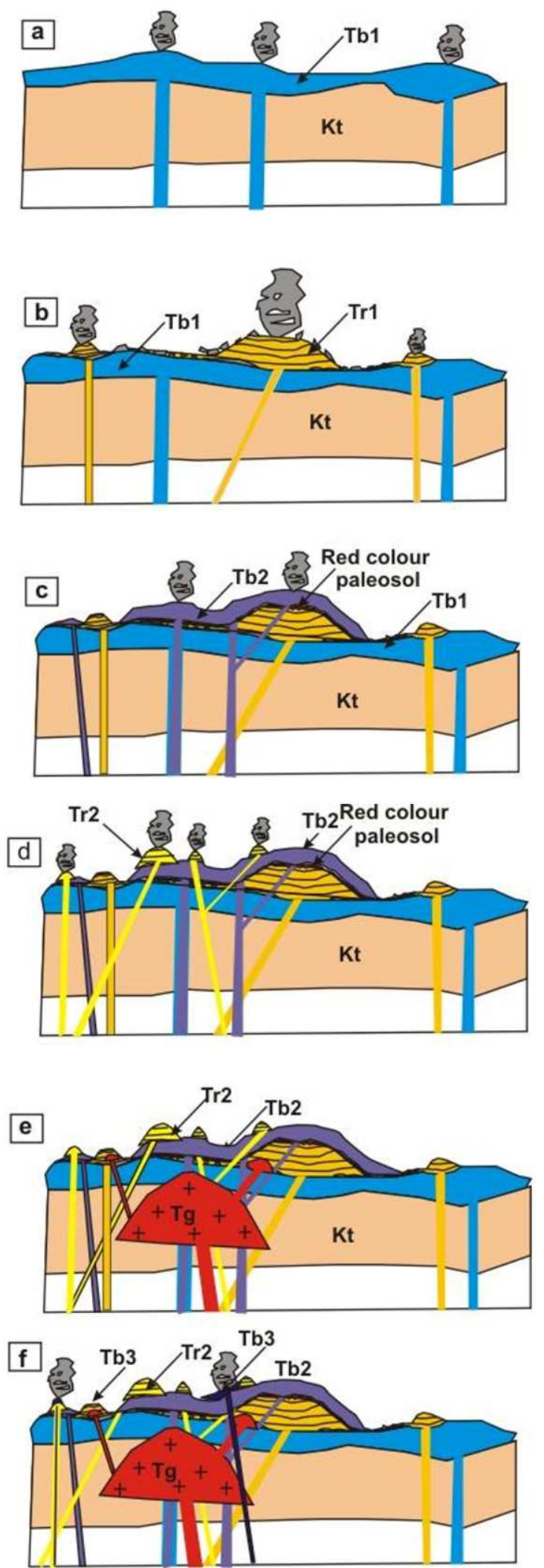


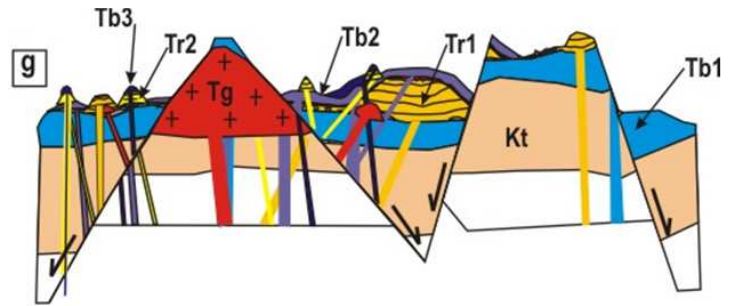

Figure 11. Schematic model diagrams illustrating the evolution of the Taiz Area, (a) eruption of the thick bile of Tb1 basalt above the Tawillah Sandstone group, (b) Extrusion of rhyolite with explosion led to extrusion of volcaniclastic materials with thyolite flows (Tr2), (c) Eruption of the Tb2 basalt over saprolitic bole (paleosol) weathered surface, (d) Extrusion of rhyolite flows and volcaniclastic materials in the dome complex, (e) Emplacement of the Saber granite and it's associated offshoots, $(f)$ Eruption of the youngest basalt as cap above Tr2 silicic rocks and locally above Tb2 basalt and, (g) Normal faulting, where the granite is exposed as a result of the faulting and erosion of the footwall block.

\section{References}

[1] Wanming, D., Cenozoic volcanism and intraplate subduction at the northern margin of the Tibetan plateau Chinese J. of Geo. Ch. Research, vol. 10. (2), pp140-152, 1991.

[2] Xia, L., Li, X., Ma, Z., Xu, X., and Xia, Z., Cenozoic volcanism and tectonic evolution of the Tibetan plateau Gondwana Research, vol. 19. (4), pp850-866, 2011.

[3] Wang, X.K., Qiu, S.w., Song, C.c., Kulakov, A., Tashchi, S., and Myasnikov, E., Cenozoic volcanism and geothermal resources in Northeast China. Geo. Sc. Chinese., vol. 11. (2), 2001, pp150-154.

[4] Dickinson, W., Tectonic implications of Cenozoic volcanism in coastal California. Overview, Geo. Soc. Bull. America. , vol. 109. (8), August 1997, pp936-954.

[5] Cioni, R., Salaro, L., and Pioli, L., The Cenozoic volcanism of San Pietro Island (Sardinia, Italy). Rendiconti Seminario Facoltà Scienze Univ. Cagliari Supplemento, vol. 71. Fasc. 2, 2001.

[6] Beydoun, Z. R. Southern Arabia and northern Somalia: comparative geology: Phil. Trans. Roy. Soc. London, 267: 267-292, 1970 .

[7] Bertrand, H., Chazot, G., Blichert-Toft, J., and Thoral, S. Implications of widespread high- $\mu$ volcanism on the Arabian Plate for Afar mantle plume and lithosphere composition. Chemical Geology. 198: 47-61, 2003.

[8] Al-Kadasi, M. Temporal and spatial evaluation of the basal flow of the Yemen Volcanic Group. Unpublished Ph. D. Thesis, Royal Holloway Collage, Landon university, UK. $301 \mathrm{pp}, 1994$.

[9] Davidson, A., and Rex D.C. Age of volcanism and rifting in southwestern Ethiopia. Nature. 283: 657-658, 1980.

[10] Baker, J.A., Snee, L., and Menzies, M. A brief Oligocene period of flood volcanism: implications for the duration and rate of continental flood volcanism at the Afro-Arabian triple junction. Earth Planet Sci. Lett. 138: 39-55, 1996a.

[11] Hofmann, C., Courtillot, V., Feraud, G., Yirgu, E., Ketefo, E., and Pik, R. Timing of the Ethiopian flood basalt event and implications for plume birth and global change. Nature. 389: 838-841, 1997.

[12] Rochette, P., Tamrat, E., Feraud, G., Pik, R., Courtillot, V., Ketefo, E., Coulon, C., Hofmann, C., Vandamme, D., Yirgu, G. Magnetostratigraphy and timing of the Oligocene Ethiopian traps. Earth Planet Sci. Lett. 164: 497-510, 1998.

[13] Ukstins, I. A., Renne, P. R., Wolfenden, E., Baker, J. A., Ayalew, D., and Menzies, M. Matching conjugate rifted margins:40Ar/39Ar chrono-stratigraphy of pre- and syn-rift bimodal flood volcanism in Ethiopia and Yemen. Earth Planet Sci. Lett., 198: 289-306, 2002.

[14] Ukstins Peate, I. A., Baker, J. A., Al-Kadasi, M., Al-Subbary, A., Knight K. B., Thirlwall, M. F., Peate, D. W., Renne, P. R., and Menzies, M. A. Volcanic stratigraphy of large-volume silicic pyroclastic eruptions during Oligocene Afro-Arabian flood volcanism in Yemen. Bull Volcanol. 68: 135-156, 2005.

[15] Al-Kadasi, M. Geology of Gabal Saber granitic mass. Unpublished M. Sc. Thesis, Sana, a University, Yemen. 232pp, 1988.

[16] Kruck, W., and Schaffer, U. Geological map of the Republic of Yemen, Sheet Taiz. Fed. Inst. Geosci. Nat. Res., Hanover, scale 1:250,000, 1991 .

[17] Windley, B. F., Whitehouse, M. J., and Ba-battat, M. A. Early Precambrian gneiss terranes and Pan-African island arcs in Yemen, crustal accretion of the eastern Arabian Shield. Geology. 24: 131-134, 1996.

[18] Beydoun, Z. R., As-Saruri, M. A. L, El-Nakhal, H., Al-Ganad, I. N., Baraba, R. S., Nani, A. O., and Al-Awah, M. H. International lexicon of, Rebublic of Yemen (Second Edition). IUGS, Republic of Yemen Publication. 34: 245p, 1998.

[19] Garzanti,E.,Vezzoli,Ando,S.,and Castiglioni,G. Petrology of Rifted-Margin Sand (Red Sea and Gulf of Aden, Yemen):Journal of Geology,v.109,p.277-297, 2001.

[20] Davison, I., Al-Kadasi, M. Al-Khirbash, S. Al-Subbary A.K., Baker, J.A. Blakey, S. Bosence, D., Dart, C., Heaton, R., McClay, K., Menzies, M., Nicols, G., Owen, L., and Yelland, A. Geological evolution of the southeastern Red Sea Rift margin, Republic of Yemen. Bull. Geol. Soc. Am. 106: 1474-1493, 1994.

[21] Civetta, L., LaVolpe, L., and Lirer, L. K-Ar ages of the Yemen Plateau. Journal of Volcanology and Geothermal Research. 4: 307-314, 1978.

[22] Mohr, P. Ethiopian flood basalt province. Nature. v. 303, p. 577-584, 1983.

[23] Chiesa, S., La Volpe, L., Lirer, L., and Orsi, G. Geological and structural outline of the Yemen Plateau, Yemen Arab Republic. Neues Jahr Geol. 11: 641-656, 1983.

[24] Ayalew, D., Barbery,. P., Marty, B., Reisberg, L., Yirgu, G., Pik, R. Source, genesis, and timing of giant ignimbrite deposits associated with Ethiopian continental flood basalts. Geochim Cosmochim Acta. 66: 1429-1448, 2002.

[25] Mattash, M. A. Study of the Cenozoic volcanic rocks and their associated intrusive rock in Yemen in relation to rift development. Unpublished Ph.D thesis, Hungarian Academy of Sciences and Eotvos L. University., Budapest. 112pp, 1994. 
[26] Mattash, M. A., and Balogh, K. K-Ar radiometric age data on Cenozoic volcanics and their associated Tertiary intrusions from Yemen. Acta Mineralogica-Petrographica, Szeged-Hungary. 83-92, 1994.

[27] Baker, J. A., Menzies, M., and Snee, L. Stratigraphy, $40 \mathrm{Ar} / 39 \mathrm{Ar}$ geochronology and geochemistry of flood volcanism in Yemen. Mineralogical. Magazine. 58A: 42-43 (abstr.), 1995.

[28] Minissale, A., Mattash, M., Vaselli, O., Tassi, F., Al-Ganad, I., Selmo, E., Shawki N., Tedesco, D., Poreda, R., Ad-Dukhain, M. and Hazzae, M. A Geochemical Approach for the Evaluation of the Geothermal Potential in Yemen. Yemen Geoscience Bulletin. 1 (1/2): 1-19, 2009.

[29] Menzies, M. A., Baker, J., Bosence, D., Dart, C., Davison, I., Hurford, A., Al-Kadasi, M., McClay, K., Nicholas, G., AlSubbary, A. and Yelland, A. The timing of crustal magmatism, uplift and crustal extension-preliminary observations from Yemen. In Magmatism and the causes of continental break-up (ed. B. Storey et al.). Geol. Soc. Lond. Spec. Publ. 68: 293-304, 1992.

[30] Manetti, P., Capaldi, G., Chiesa, S., Civetta, L., Conticelli, S., Gasparon, M., LaVolpe, L., and Orsi, G. Magmatism of the eastern Red Sea margin in the northern part of Yemen from Oligocene to present. Tectonophysics. 198: 181-202, 1991.

[31] Baker, J. A., Thirlwall, M. F., Menzies, M. A. Sr-Nd-Pb isotopic and trace element evidence for crustal contamination of plume-derived flood basalts: Oligocene flood volcanism in western Yemen. Geochim Cosmochim Acta. 60: 2559-2581, $1996 b$.

[32] Youssef, M. H. Tectonic setting of some Miocene granite intrusions, in relations to the Aden and Red Sea rifts, southwestern border of the Yemen Plateau. Geol. Soc. Egypt., Spec. Publ. 1: 445-459, 1993.
[33] Khanbari, K. Study of Structures and Tectonic Evolution of Yemen Tertiary Granites, by Using Remote Sensing Technique. Journal of Remote Sensing issued by GORS. 21: 63-72, 2008.

[34] Capaldi, G., Chiesa, S., Manetti, P., Orsi, G., Poli, G. Tertiary anorogenic granites of the western border of the Yemen Plateau. Lithos. 20: 433-444, 1987.

[35] Huchon, P., Jestin, F., Cantagrel, J. M., Gaulier, J. M., Al Khirbash, S., Gafaneh, A. Extensional deformations in Yemen since Oligocene and the Afar triple junction. Annales Tectonicae. 5 (2): 141-163, 1991.

[36] Zumbo, V., Féraud G., Bertrand, H., and Chazot, G. 40Ar/39Ar chronology of Tertiary magmatic activity in Southern Yemen during the early Red Sea-Aden Rifting. Journal of Volcanology and Geothermal Research. 65: 265-279, 1995.

[37] Chazot, G., Bertrand, H. Genesis of silicic magmas during Tertiary continental rifting in Yemen. Lithos. 36: 69-84, 1995.

[38] El-Gharbawy, R. I. Petrogenesis of granitic rocks of the Jabal Saber area, South Taiz City, Yemen Republic. Chin. J. Geochem. 30: 193-203, 2011.

[39] Youssef, M., El-Shatoury, H. and Al-Kadasi, M." Geology of Gabal Saber Granitic Mass, Taizz, Yemen Republic" in Geology of The Arab World Conf., 1: 433-447, 1992, Cairo University, Egypt.

[40] Khanbari, K., and Huchon, P. Paleostress analysis of the volcanic margins of Yemen. Arab. J. Geosciences. 3: 529-538, 2010. 